\title{
Post Endodontic Pain Reduction using three Irrigants with Different Temperature
}

\author{
Jorge Paredes Vieyra ${ }^{1 *}$, Julieta Acosta Guardado² Fernando Calleja Casillas $^{3}$ and Alan Hidalgo Vargas ${ }^{4}$ \\ ${ }^{1}$ Autonomous University of Baja California, School of Dentistry, Mexico \\ ${ }^{2}$ Private practice in Endodontics, Mexico \\ ${ }^{3}$ Department of Biochemistry, Autonomous University of Baja California, School of Dentistry, Mexico \\ ${ }^{4}$ Clinical Assistant, Autonomous University of Baja California, School of Dentistry, Mexico
}

*Corresponding author: Jorge Paredes Vieyra, Professor in Endodontics, Autonomous University of Baja California, School of Dentistry, Tijuana Campus, Mexico

\begin{abstract}
Objective: The purpose of this research was to evaluate whether meticulous irrigation with three different temperatures would help in a decrease dental pain.

Materials and Methods: All 120 patients had teeth chosen for conventional RCT for prosthetic reasons in teeth with vital pulps. All canals were cleaned and shaped with Reciprocal files. Final irrigation was done with cold saline solution $\left(6^{\circ} \mathrm{C}\right.$, $4{ }^{\circ} \mathrm{C}$, and room temperature).

Results: A total of 120 of 135 patients (69 females and 51 male) were included whereas 15 were excluded as not achieving the necessities of the study. All patients presented with a vital upper or lower molar, premolar, or front teeth. No statistically major change $(\mathrm{P}>0.05)$ between the groups was found regarding the degree or duration of pain.

Conclusion: The approach in both selecting the patients participating in the research and analyzing the data in this research allows us to determine that cryotherapy is an aid of clinical procedures to clean and shape the canals to decrease the occurrence of post-endodontic pain and the need for medication in patients presenting with a diagnosis of vital pulp.
\end{abstract}

Keywords: Apical healing; Flare-ups; Pain; Post endodontic pain; Post-operative pain

\section{Introduction}

Post-endodontic pain is an undesirable sensation occurred in patients regardless of the preoperative periapical status of the tooth treated. Therefore, prevention and management of post endodontic pain are essential in endodontic practice [1]. Organic material, microorganisms, and irrigating solutions extruding beyond the apical constriction during root canal therapy (RCT) will originate inflammation and periodontal ligament complications, such as severe pain or flare-ups. It must be noticed that the amount of extruded material (debris and/or irrigate) varies widely in the reported studies which indicate problems and inconsistencies in treatment methodologies [2-4]. Recent literature has showed that keeping apical patency would not generate more postoperative difficulties [5-7]. A recently issued in vitro study showed that intracanal delivery of cold irrigating solution at $2.5^{\circ} \mathrm{C}$ with negative pressure flushing reduced the external surface temperature to close $10{ }^{\circ} \mathrm{C}[8-10]$, would be enough to create a local anti-inflammatory beneficial consequence in peri radicular tissues. Cryotherapy proposes that using cold over some procedures may decrease the diffusion of nerve signs, bleeding, edema, and local inflammation and is therefore effective in the reducing of pain. Therefore, the purpose of this research was to evaluate whether meticulous irrigation with three irrigating practices with different temperature would help in a decrease of post-endodontic pain. 
Three expert endodontists with a private practice of 17 years and skilled in the procedures and procedures studied were included in the research and performed 40 RCTs each (a total of 120) in upper/ lower front or back teeth with irreversible pulpitis recognized by pulp sensitivity testing with hot and cold. Pulpal response tests were achieved by the main author, and a digital $\mathrm{X}$ ray diagnosis was documented by three certified clinicians. Additional clinical necessities for patients' inclusion were as follows: Necessities of the research were agreed and spontaneously accepted, healthy patients were included, teeth with enough coronal structure and diagnosed with vital pulps, no previous RCT, and no analgesics or antibiotic consumption 7 days before the procedures. A total of 120 of 135 patients ( 69 females and 51 male) aged 18 - 60 years were referred and integrated in this research, whereas 15 were rejected as not accomplishing the necessities wanted. All participants showed with a vital upper or lower molar, premolar or front teeth designated for conventional RCT for dental rehabilitation reasons.

\section{Methods}

\section{Dental procedures}

Root canal treatment was done in one visit. Topical anesthetic (Anesthesia Topical, Astra, Mexico) was used. Patients received 2 carpules of articaine 2\% with epinephrine 1:200,000 (Septodont, Saint-Maur des-Fosses, France). Situations in which supplementary anesthesia was needed, intra-ligamental anesthesia $(2 \mathrm{~mL}$ articaine $2 \%$ ) was supplied. For the upper front teeth, the solution was administered by tender and slow local infiltration. For the lower teeth, one of the carpules was used for the lingual and alveolar nerve block, the other one for a moderate bucal infiltration nearby the tooth to be treated.

\section{Irrigation protocols}

a) Group $6{ }^{\circ} \mathrm{C}$. The R25 (size 25/ .08) instrument was employed in tinny and curved canals, and R40 files (40/.06) were used in broad root canals. Three in-and-out pecking series were employed with a fullness of not more than $3 \mathrm{~mm}$ until getting the calculated WL. Patients allocated to this group receive a final irrigation with $5 \mathrm{~mL}$ of cold $\left(6{ }^{\circ} \mathrm{C}\right) 17 \%$ EDTA followed by $10 \mathrm{~mL}$ of cold $\left(6{ }^{\circ} \mathrm{C}\right)$ sterile saline solution dispensed to the $\mathrm{WL}$ using a cold $\left(6^{\circ} \mathrm{C}\right)$ metallic micro-cannula.

b) Group 4: Canals were instrumented as in group A. Patients allocated to this set received a final irrigation with $5 \mathrm{~mL}$ of cold $\left(4{ }^{\circ} \mathrm{C}\right) 17 \%$ EDTA followed by $10 \mathrm{~mL}$ of cold $\left(4^{\circ} \mathrm{C}\right)$ sterile saline solution dispensed to the WL using a cold $\left(4^{\circ} \mathrm{C}\right)$ metallic microcannula for 1 minute.

c) Group RT: The R25 (size 25/ .08) instrument was employed in tinny and curved root canals, and R40 files (40/ .06) were used in wide canals. Three in-and-out series were employed with a space of not more than $3 \mathrm{~mm}$ until getting the calculated WL. Reciprocal instruments were used in one tooth only (single use). Participants allocated to this control group were treated similarly to the experimental groups, except that they received a final flush with $5 \mathrm{~mL}$ (room temperature) of $17 \%$ EDTA followed by $10 \mathrm{~mL}$ (room temperature) of sterile saline solution delivered to the WL.

\section{Statistical analysis}

The related issues preoperatively recorded were integrated into the examination as follows: age and sex, occlusal contacts, and maxilla or mandibular teeth. Changes in the strength of pain among groups were studied using the ordinal (linear) X2 test. Variances in VAS-recorded standards after 24, 48, and 72 hours and in the quantity of analgesic intake among the two groups tested.

\section{Results}

Table 1: Distribution by group of teeth and location.

\begin{tabular}{|c|c|c|c|}
\hline \multicolumn{4}{|c|}{ Irrigants Protocols } \\
\hline Variables & $\begin{array}{c}\text { Control Group } \\
\text { RT }(n=40)\end{array}$ & $\begin{array}{c}\text { Group } 6{ }^{\circ} \mathrm{C} \\
(n=40)\end{array}$ & $\begin{array}{c}\text { Group } 4{ }^{\circ} \mathrm{C} \\
(n=40)\end{array}$ \\
\hline \multicolumn{4}{|c|}{ Sex } \\
\hline Male & 17 & 17 & 17 \\
\hline Female & 23 & 23 & 23 \\
\hline \multicolumn{4}{|c|}{ Age Group } \\
\hline $18-30$ & 25 & 21 & 29 \\
\hline $31-43$ & 40 & 43 & 41 \\
\hline $44-56$ & 11 & 13 & 7 \\
\hline $57-60$ & 4 & 3 & 3 \\
\hline \multicolumn{4}{|c|}{ Arch } \\
\hline Maxilla & 28 & 27 & 32 \\
\hline Mandible & 11 & 13 & 9 \\
\hline \multicolumn{4}{|c|}{ Occlusal contact } \\
\hline Yes & 6 & 4 & 4 \\
\hline No & 34 & 36 & 36 \\
\hline
\end{tabular}

Table 2: Kruskal/Wallis test applied to the post-endodontic pain.

\begin{tabular}{|c|c|c|c|}
\hline Occurrence of Pain & n & Mean & Standard Deviation \\
\hline \multicolumn{3}{|c|}{ Pain after 24h } \\
\hline Control Group RT & 40 & 0.58 & 0.82 \\
\hline Group $6{ }^{\circ} \mathrm{C}$ & 40 & 0.66 & 0.83 \\
\hline Group $4{ }^{\circ} \mathrm{C}$ & 40 & 0.88 & 0.97 \\
\hline Pain after $48 \mathrm{~h}$ & & & 0.44 \\
\hline Control Group RT & 40 & 0.25 & 0.43 \\
\hline Group 6 ${ }^{\circ} \mathrm{C}$ & 40 & 0.254 & 0.60 \\
\hline Group $4{ }^{\circ} \mathrm{C}$ & 40 & 0.22 & 0.83 \\
\hline Pain After $72 \mathrm{~h}$ & & & 0.82 \\
\hline Control Group RT & 40 & 0.02 & 0.97 \\
\hline Group 6 ${ }^{\circ} \mathrm{C}$ & 40 & 0.04 & \\
\hline Group $4{ }^{\circ} \mathrm{C}$ & 40 & 0.05 & \\
\hline
\end{tabular}

Table 1 displays the distribution of variables; a total of 120 participants took part in this study: 69 (57.5\%) were women, and 51 (42.5\%) were men. The ages fluctuated among 18 and 60 
years; 87 (72.5\%) were upper teeth, and 33 (27.5\%) were lower teeth. The clinical management of the patients is showed in Table 1. No significant modification $(P>0.05)$ between the groups was encountered concerning the grade or period of pain. Rendering to the VAS examination, marks were seen $24-72$ hours late in the 3 groups with a significant decline successively (Tables $2 \& 3$ ).

Table 3: Results of VAS. Intensity of Pain.

\begin{tabular}{|c|c|c|c|}
\hline Occurrence & $\begin{array}{c}\text { Control Group } \\
\text { RT (n=80) }\end{array}$ & $\begin{array}{c}\text { Group A 6 } \\
\text { (n=80) }\end{array}$ & $\begin{array}{c}\text { Group 4 }{ }^{\circ} \mathbf{C} \\
\text { (n=80) }\end{array}$ \\
\hline No & 54 & 57 & 57 \\
\hline Yes & 26 & 23 & 23 \\
\hline Mild & 13 & 10 & 11 \\
\hline Moderate & 13 & 12 & 12 \\
\hline Intense & 1 & 1 & 0 \\
\hline
\end{tabular}

\section{Discussion}

Pain is tough to comprehend and calculate especially when it occurs unexpectedly in patients. The major trouble in knowledge painful and discomfort is the participant's individual valuation and its dimension. For this objective, organization of the estimation form has to be entirely understood by participants. In our research, a simple spoken classification was followed in the feedback procedure with four classes: no pain, slight, modest, and intense pain. These classes were clearly comprehended by participants and were described by the occurrence or nonappearance of the necessity for pain-relieving treatment. Preoperative pain is one of the main predictors of post-endodontic pain [11-14]. Thus, only teeth with irreversible pulpitis indicated for RCT because of prosthodontic purposes were treated in this research. In our research, we reduced the variation in the procedures following protocols based on recommendations by authors and manufacturers. While successful endodontic treatment depends on various variables, an important point to consider in the shaping of the root canal system is the amount of the irrigating solution. Proper disinfecting and filling the root canal system is facilitated by the keeping of its original shape from the entrance to the apical third, without any iatrogenic event.

\section{Conclusion}

According to the conditions established for this study, there was no statistically significant difference between the instrumentation systems assessed.

\section{References}

1. Ince B, Ercan E, Dalli M, Dulgergil CT, Zorba YO, et al. (2009) Incidence of postoperative pain after single- and multi-visit endodontic treatment in teeth with vital and non-vital pulp. Eur J Dent 3(4): 273-279.

2. Tanalp J, Güngör T (2014) Apical extrusion of debris: A literature review of an inherent occurrence during root canal treatment. Int Endod J 47(3): 211-221.

3. Ferraz CC, Gomes NV, Gomes BP, Zaia AA, Teixeira FB, et al. (2001) Apical extrusion of debris and irrigants using two hands and three enginedriven instrumentation techniques. Int Endod J 34: 354-358.

4. Bürklein S, Schëafer E (2012) Apically extruded debris with reciprocating single-file and full-sequence rotary instrumentation systems. J Endod 38: 850-852.

5. Torabinejad M, Kettering J, McGraw J, Cummings RR, Dwyer TG, et al. (1988) Factors associated with endodontic interappointment emergencies of teeth with necrotic pulps. J Endod 14: 261-266.

6. Hülsmann, M, Peters O, Dummer P (2005) Mechanical preparation of root canals: Shaping goals, techniques and means. Endod Top 10: 3076.

7. Hülsmann M (2008) Extrusion von Debris und Spülflüssigkeiten während der Wurzelkanalbehandlung. Endodon 17: 353-354.

8. Souza RA (2006) The importance of apical patency and cleaning of the apical foramen on root canal preparation. Braz Dent J 17: 6-9.

9. Hülsmann M, Schäfer E (2009) Apical patency: Fact and fiction - a myth or a must? A contribution to the discussion Endo Endod Prac T 3(4): 285-208.

10. Roane JB, Sabala CL, Duncanson MG (1985) The "balanced force" concept for Instrumentation of curved canals. J Endod 5: 203-211.

11. Monsef M, Hamedzadeh K, Soluti A (1998) Effect of apical patency on the apical seal of obturated canals. J Endod 24: 284.

12. Flanders D Endodontic patency: How to get it, how to keep it, why it is so important. NY State Dent J 68(3): 30-32.

13. Yared G (2008) Canal preparation using only one Ni-Ti rotary instrument: Preliminary observations. Int Endod J 41: 339-344.

14. Reddy SA, Hicks ML (1998) Apical extrusion of debris using two hands and two rotary instrumentation techniques. J Endod 24: 180-183.

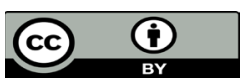

This work is licensed under Creative Commons Attribution 4.0 License

To Submit Your Article Click Here: Submit Article
DOI: $10.32474 /$ SJO.2019.02.000134

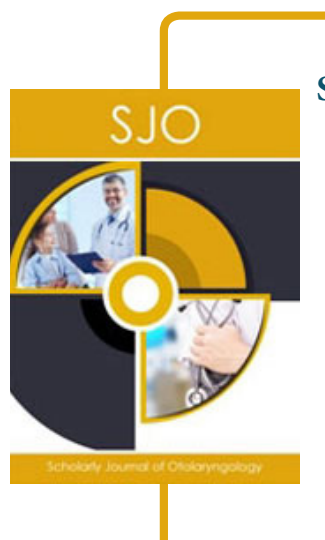

\section{Scholarly Journal of Otolaryngology}

\section{Assets of Publishing with us}

- Global archiving of articles

- Immediate, unrestricted online access

- Rigorous Peer Review Process

- Authors Retain Copyrights

- Unique DOI for all articles 